\title{
Searching for the past, building for the future
}

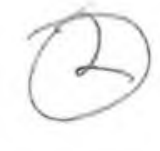

\author{
By Susan M. Campbell \\ Library Director \\ York College of Pennsylvania
}

and Michael J. Haeuser

College Librarian

Gustavas Adolphus College

\section{The College Libraries Section celebrates 100 years.}

\begin{abstract}
A s ACRL, or more correctly the original College Library Section, celebrates its one hundredth anniversary, it seems appropriate to reflect on the work of the College Libraries Section (CLS) Historical Commission. At the ALA Annual Conference in 1985, Jean Pelletiere, chair of the College Libraries Section, gathered with a small group of people to talk about conducting some research on the section. Significantly, a section review in the early 1980s may have been the point at which CLS officers became concerned about what the section was doing. Each subsequent chair responded with new initiatives. Pelletiere envisioned a section history and manual. Together the two elements would establish a document that would provide a sense of continuity for the section and serve as a helpful reference for section officers, committee chairs, and others interested in the functions of the organization, nearing its centennial year.

Out of these discussions the College Libraries Section Historical Commission (ad hoc) was formed and formally charged "to prepare a history of the Section, collecting and suggesting procedures, and assembling those procedures into a Section manual." Original members of the Commission were Susan Campbell (chair), Mike Haeuser, Michael LaCroix, David Norden, and Robert Schirmer. Claudette Hagle and Clarence Toomer joined the group in 1987.

The group met for the first time at the Midwinter Meeting in 1986 and mapped several strategies
\end{abstract}

to obtain information to prepare a history of the section. ALA Archives and Headquarters personnel provided names of past officers and candidates for office. The Historical Commission developed a questionnaire to solicit information on extant documentation, programs, notable events, successes, and failures of the College Libraries Section. The intention was to determine a sense of evolutionary development over a considerable period of time. In spite of the efforts of some past and present section officers, the survey results were less than illuminating. They established that the task would be more difficult than the Commission had believed. Still, the returns did inspire the next effort to find historical information.

An oral history project was planned. Five people who have been active in the section agreed to be interviewed individually by the Historical Commission at the Midwinter Meeting in 1988. They included Dale Carrison, Evan Farber, Tom Kirk, William Moffett, and John Sheridan. In a marathon day-long session, the Commission asked each to reminisce about the history of the section, its development, and the problems and positive outcomes they observed. Finally, each made some strong recommendations for the future of the section.

Although not much historical information was obtained, the interviews provided all present with a sense of the importance of college libraries in American higher education and the responsibility 
of the College Libraries Section in promoting that role. While many facets of the section were discussed during the interviews, Historical Commission members were impressed at the recurrence of several themes, both with respect to the history of the section and to its future. The interviewees mentioned section publications (CLIP Notes and CLS Newsletter), growing membership, participation at all levels of librarianship, strong annual programs, and growing responsiveness to member concerns as evidence of current section strengths, members' commitments, and leadership efforts.

Looking at the past, they were concerned about similar issues. "The section was important when colleges were important," quipped Farber, alluding to the once unquestioned pre-eminence of "colleges" in the national higher education structure. The development of land grant universities, state teachers' institutions and community colleges on the one hand and the diversification of the curriculum on the other, produced an identity crisis and left the CLS seeking an identity in its wake. The College Libraries Section may suffer not only from its name "College Libraries," which is nowhere defined, but also from its objective as stated in the bylaws, "to advance college librarianship and encourage the development of library services in baccalaureate degree-granting institutions." $\mathrm{Mem}$ bers of type-of-library sections have less cohesive concerns than members of type-of-activity sections. Demography and geography have worked against the section, keeping newer professionals from attending national meetings. The structure of professional education and its proclivity towards specialization is biased toward the organization of university librarians. CLS has no organization goals and there has been no long-term planning. The section, therefore, in spite of its strengths, lacks definition and continuity.

Searching for history gave much insight into the section's strengths and weaknesses. Perhaps the most important aspect of these conversations, however, was the optimism that these college library leaders expressed as they looked to the future. There was concern for definition of college libraries, of college librarians, and of the College Libraries Section. Further, the problems of college libraries need to be defined and appropriate forums for addressing the problems developed. They cited the role of the section in providing forums for communication among college librarians. All were confident that CLS members were rising to meet these challenges and noted that new committees, e.g., the National Advisory Council, the Newsletter Committee, and the Standards Committee will help. The Library Directors Discussion group will, too. Development of a long-range plan also seems essential to insure continuity.

CLS needs to explore ways to more widely disseminate programming for college librarians. Repeatedly, interviewees called for increased cooperation with ACRL chapters, type of activity sections, or state and regional organizations to make programming available to those who cannot regularly attend ALA and to provide opportunities for people to become visible by involvement. Most felt restructuring CLS to accomplish this would not be beneficial, but that exploring other avenues within ACRL could do much to promote programs at the state and regional level for college librarians.

Further, the section must find ways to promote college librarianship as an attractive career choice and to encourage bright college students to enter library school with that commitment. The organization must also assist college librarians in their recruitment efforts.

In conclusion, the CLS Historical Commission found the task of preparing a comprehensive history of the section challenging, engaging, and difficult. It found little documentation. Those historical materials discovered were haphazardly collected and organized. The Commission found little evidence of long-term, systematic planning for the section's activities. An oral tradition, rather than a written one, characterized the institutional memory. A lack of continuity in activities and interests was noted. The focus at any given time tended to reflect the interests and concerns of the current chair rather than long-term programmatic planning.

As a consequence of its endeavors, the Historical Commission produced the Manual of the College Libraries Section of ACRL. The document was presented to the CLS Executive Committee at the Midwinter Meeting in Washington in January. In addition, the Commission made formal recommendations to the Executive Committee concerning the organization of the section, its management, and its planning structure.

The College Libraries Section enters its second century with growing strength, active commitment from its members, and a renewed sense of purpose.

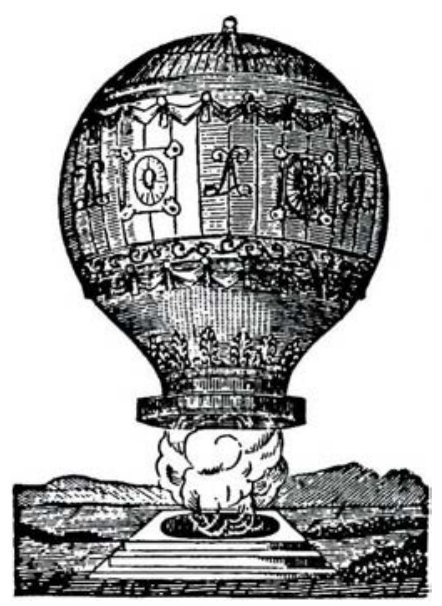




\section{ULS Current Topics Discussion Group at Midwinter}

The University Library Section Current Topics Discussion Group, which was formed in 1986 in response to the need for a small group setting where university librarians can discuss "hot topics," sponsored a lively session at the Midwinter Meeting in January. The role of risk-taking and creative innovation in library decision making was examined by three provocative speakers in an informal small group setting. Utilizing an innovative format, which has been this group's hallmark, Risky Business: Decision Making and the Library Budget, encouraged librarians to examine their own values and attitudes towards risk-taking and invited a new spirit of entrepreneurship in coming up with creative solutions to the problem of funding new programs and initiatives in university libraries.

In the opening presentation in which the medium certainly was the message, Shelley Phipps of the University of Arizona kicked things off with a risky proposition for the audience. She asked for volunteers who would be willing to choose one of a series of card or quiz games and play them with her, risking their own real money against the chance of winning real money from Shelley. The volunteers, who all won, shared with the group the factors that went into their choice of game as they tried to assess the potential gains and losses involved.

Susan Jurow of the Office of Management Services placed these reactions in context by defining risk and presenting a useful risk assessment model developed by Kenneth MacCrimmon. This model uses a five-step approach: recognize risk; evaluate risk; adjust risk by gaining control, information, or time; choose among alternatives; track on outcomes.

A series of stimulating case studies presented by George Soete of the University of California at San Diego, provided the opportunity for small groups to get some hands on experience with the riskassessment model. These scenarios which involved such timely issues as document delivery services, affirmative action hiring, and subcontracting of library facilities and services, served as the basis for a series of lively exchanges among participants.

Perhaps the most interesting portion of the session was a freewheeling brainstorming segment in which librarians were asked to come up with ideas to increase risk capital in academic libraries. Such creative approaches as encouraging patrons to "adopt a serial," rent a carrel or taking out a bank loan in order to finance an integrated library system, were tossed out. The whole notion of a new entrepreneurial spirit in academic libraries obviously touched a responsive chord in the attendees.

The discussion topic for the Dallas conference, tentatively scheduled for Sunday, June 25 , has been selected. It will deal with issues relating to library services to outside users, the so-called secondary clientele. More details will be available in the May 1989 issue of C $\forall R L$ News.-Beverly Feldman, Head of Reference, State University of New York at Buffalo.

\section{ACRL executive summary}

\section{Professional development}

The Humanities Programming Workshop for Historically Black Colleges and Universities (HBCUs), funded by the National Endowment for the Humanities and sponsored by ACRL and PLA, was held in Atlanta, February 22-24. We had 16 wonderful teams from HBCUs and their community libraries, excellent humanities scholars and instructors, and participants who developed topnotch ideas for programs. We expect to see a number of these funded in future rounds of competition at NEH.

A new proposal was developed for another series of humanities workshops; PLA and ACRL submitted the proposal to NEH in March.

\section{Enhancing service capability}

An increase in advisory and information calls has resulted from publicity about the Cincinnati conference. We are happy to hear from so many interested people!

\section{Liaison and advocacy}

The Council on Postsecondary Accreditation held a workshop on the role of libraries and computer centers in the accreditation process.

\section{Research and publication}

Tape sales of Books for College Libraries are doing well. We will next consider other non-print formats. 
Strategic management directions

The ALA Membership System generated its first set of labels for new members. New member kits were mailed to all new ACRL members.

The 1990 preliminary budget was submitted to
ALA Fiscal Services. It anticipates a heavy deficit, and is what has motivated the ACRL Budget and Finance Committee to recommend a dues increase.-JoAn S. Segal, ACRL Executive Director.

\author{
By Louise S. Sherby \\ Chair, ACRL Professional Association Liaison Committee
}

\title{
PALC tousiness \\ ACRL professional liaison activities
}

\section{ACRL looks for more links to other organizations.}

T he ACRL Professional Association Liaison Committee (PALC) has spent the last several years working towards the strengthening of ACRL's relationships with other professional associations. The committee has done this in several ways.

First, the committee has awarded grants to individual members in support of their activities in non-library professional associations. A PALC grant supported the participation of Gloria Smith, University of Arizona, in presenting a panel at the Twelfth Annual National Council of Black Studies in Philadelphia in April 1988. The idea for this panel grew out of Smith's earlier involvement in the Black History Internship Project at the Arizona Historical Society. The purpose of this project was to learn about local African-American history. In addition to collecting individual oral history, family photos and surveying existing materials of the society, the group was trained in oral history techniques and in techniques for working with older residents. This activity led to Smith's continuing involvement in local African-American history and ultimately to her organizing a panel presentation for the National Council of Black Studies Conference. Smith's paper explained the project's Historical Happening at the Arizona Historical Society. As she indicates in her report to the committee, "This panel shows how librarians can be productive in acquiring community history and can work effectively with professionals of other disciplines. It also shows how a library, the Arizona Historical Society, can be productive in helping a community to gather, preserve and display its ethnic heritage."

Another ACRL member who received support was Martha L. Brogan, University of Minnesota. Brogan participated in the fourth biennial Interdisciplinary Conference for Netherlandic Studies (ICNS) in June 1988. As she reports to the committee: "The ICNS is sponsored by the American Association for Netherlandic Studies (AANS), a national scholarly organization formed in 1982 to promote the study of the language, literature, and culture of the Netherlands and Dutch-speaking Belgium. Its 250 members are primarily engaged in teaching and research in the field of Dutch studies in the United States.

"For the 1986 ICNS conference I proposed to write a paper analyzing the content of the RLG Conspectus relevant to Dutch studies. It was rejected on the grounds that it didn't fit into any of the pre-ordained program areas. Undeterred, I tried again in 1988, only this time I proposed to organize an entire session-'High Tech in the Lowlands: Library Resources in the Electronic Age'- 